\author{
Магденко С.O. \\ асистент \\ кафедра економіки промисловості \\ Одеська національна академія харчових технологій \\ вул. Канатна, 112, г. Одеса, Україна, 65039 \\ E-mail: maglana@meta.ua
}

\title{
ВІДНОСИНИ ВЛАСНОСТІ ЯК ОСНОВНА СКЛАДОВА ФОРМУВАННЯ СУЧАСНОГО РИНКОВОГО ГОСПОДАРСТВА УКРАЇНИ
}

У статті розглянуті форми, типи та види власності, що притаманні сучасному ринковому господарюванню, тенденції формування сучасних форм власності, їхній взаємозв'язок з формами господарювання підприємств харчової промисловості.

Ключові слова: власність, форми власності, види власності, форми господарювання, ефективність, ринкове господарство, суб'єкт господарювання.

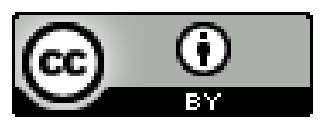

Постановка проблеми та її зв'язок з важливими науковими та практичними завданнями. Питання формування сучасного ринкового господарства пов'язані із застосованими відносинами власності. Ті вимоги, що характерні для сучасного ринкового господарства, розвитку форм господарства, створення конкурентного середовища для суб'єкта господарювання безпосередньо залежать від форм, видів і типів власності. Зараз це важливо для України. Інша сторона питання - це форми реалізації відносин власності.

Зміна форм і видів власності - це не самоціль, а лише спосіб для забезпечення можливості подальшого розвитку країни до ринкових відносин.

Аналіз останніх публікацій по проблемі. Питання відносин власності розглядають практично всі вчені, але з різних позицій, відповідно предмету дослідження: Геєць В.М., Гальчинський А., Бородюк В., Лукінов I.I., Мандибура В.О., Чухно А.А. та інші. Науковці визнають, що власність у системі відносин $€$ базовою складовою, яка відображає, в першу чергу, відношення в суспільстві щодо привласнення основних засобів.

Формулювання цілей дослідження. Метою дослідження є розкриття тенденцій формування сучасних форм власності, що притаманні сучасному ринковому господарству, визначення особливостей щодо форм та видів власності України, зокрема суб'єктів господарювання м'ясопереробної галузі.

Виклад основних результатів та їх обгрунтування. Як головна категорія в системі суспільних відносин, власність характеризує відносини з приводу привласнення, володіння та розпорядження між людьми матеріальних благ і послуг, i, в першу чергу, основних засобів. 3 точки зору виконання власністю функцій, ми погоджуємося 3 тими характеристиками ïx, які розглянуті в роботі В. Мандибури [1, с. 57-58]:

По-перше, власність зумовлює спосіб та визначає найбільш характерні мотиваційні особливості поєднання трудового потенціалу та засобів виробництва, фінансовими і природними ресурсами.

По-друге, власність, визначає мету функціонування і розвитку економічної системи.

По-третє, власність визначає характер економічного розподілу та кінцевого привласнення та споживання результатів виробництва (життєвих благ та послуг).

По-четверте, власність формує суспільний та персоніфікований характер мотивації трудової і підприємницької діяльності.

По-п'яте, відносини власності формують соціально-класову структуру суспільства, забезпечують базові засади розвитку системи панівної політичної та економічної влади.

Проблеми класифікації власності в сучасних умовах $є$ одним $з$ найскладніших питань. Це питання взаємодії форм, видів і типів власності, та їх наповнення змістом, які не мають єдності між вченими. Критичний аналіз єдності цих категорій наведено в роботах Мандибури В., які він групує в п’ять різних підходів. [1, с. 59-60]

Форма власності є зовнішнім організаційноекономічним проявом відносин приналежності, володіння, розпорядження та використання того чи іншого типу або виду власності, тобто форма власності $\epsilon$ похідною від типа і виду власності, структури їі побудови. В системі власності особливе місце займає державна власність. Проте на сучасному етапі господарювання спостерігається негативне відношення до державної власності, їі значне скорочення як вартісне, так i фізично. Зазначена тенденція може привести бюрократію до отримання доходу тільки шляхом 
зловживань. Але критика державної власності та державного керівництва як такого, на нашу думку, повинна враховувати реалії держави, менталітет суспільства, етнічні властивості регіонів держави.

Кожна форма власності може мати певні ор- ганізаційно-економічні види господарювання. Для України характерні види і структура організаційних форм, які мають різний організаційно-економічний рівень, кількість та питому вагу (табл. 1).

Таблиця 1

Кількість суб'єктів економіки України за організаційними формами [11]

\begin{tabular}{|l|c|c|}
\hline & Кількість & Питома вага, \% \\
\hline Усього юридичних осіб, & 1112757 & 100,0 \\
\hline у тому числі: & & 0,36 \\
\hline- державне підприємство & 4030 & 1,03 \\
\hline- комунальне підприємство & 11443 & 1,41 \\
\hline- акціонерні товариства & 15672 & 3,92 \\
\hline- фермерське господарство & 43617 & 5,56 \\
\hline- комунальна організація (установи, заклади) & 61913 & 6,22 \\
\hline- громадська організація & 69175 & 9,19 \\
\hline- органи влади, організації (установи, заклади) & 102280 & 18,15 \\
\hline- приватне підприємство & 201967 & 43,30 \\
\hline- товариство з обмеженою відповідальністю & 481836 & 16,42 \\
\hline- інші організаційні форми & 182737 & \\
\hline
\end{tabular}

За даними таблиці 1 найбільшу питому вагу серед зареєстрованих юридичних осіб займають суб'єкти господарювання - товариства 3 обмеженої відповідальністю (43,30 \%), на другому місці - приватні підприємства $(18,15 \%)$. Частка фермерських господарств становить 3,92 \%, акціонерних товариств - 1,41, держаних підприємств - лише 0,36\%.

Ti особливості, що притаманні механізмам державного і ринкового регулювання країнам Заходу, де відношення до приватної власності було звичайної справою, $є$ не зовсім прийнятними країнам колишнього СРСР. Це також є проблемою і для України.
Неможливо однаково для всіх регіонів країни підходити до вирішення питання щодо їх розвитку.

Питання приватної власності для західних регіонів країни розглядаються також позитивно, тоді як для східної частини більш характерні колективні форми власності. Це психологічні моменти, які треба враховувати при напрямку розвитку певного регіону.

Для харчової промисловості державна власність і державні підприємства не є актуальними. Підтвердженням цього є розподіл суб'єктів господарювання м'ясопереробної галузі за формами власності по регіонам України, наданий в таблиці 2.

Таблиця 2

Питома вага м'ясопереробних підприсмств України за формами власності

\begin{tabular}{|l|c|c|c|}
\hline \multirow{2}{*}{ Область /регіон України } & \multicolumn{2}{|c|}{ Питома вага підпиємств 3 формами власності, \% } \\
\cline { 2 - 4 } & приватної & колективної & державної \\
\hline м. Севастопіль & 40,00 & 60,00 & 0,00 \\
\hline Запорізька & 41,67 & 58,33 & 0,00 \\
\hline Київська & 41,84 & 56,12 & 2,04 \\
\hline Сумська & 42,86 & 57,14 & 0,00 \\
\hline Харківська & 44,12 & 55,88 & 0,00 \\
\hline Херсонська & 45,00 & 55,00 & 0,00 \\
\hline Житомирська & 45,45 & 54,55 & 0,00 \\
\hline Дніпропетровська & 47,22 & 52,78 & 0,00 \\
\hline Одеська & 49,06 & 50,94 & 0,00 \\
\hline Полтавська & 50,00 & 50,00 & 0,00 \\
\hline Волинська & 53,13 & 46,88 & 0,00 \\
\hline м.Київ & 53,57 & 46,43 & 1,22 \\
\hline Вінницька & 53,66 & 45,12 & 2,86 \\
\hline Черкаська & 54,29 & 42,86 & 0,00 \\
\hline Донецька & 55,42 & 44,58 & 0,00 \\
\hline Луганська & 56,25 & 43,75 & 0,00 \\
\hline Чернігівська & 56,67 & 43,33 & 0,00 \\
\hline Львівська & 60,00 & 40,00 & \\
\hline
\end{tabular}




\begin{tabular}{|c|c|c|c|}
\hline \multicolumn{4}{|c|}{ Продовження табл.2 } \\
\hline Чернівецька & 62,50 & 37,50 & 0,00 \\
\hline Рівненська & 67,03 & 30,77 & 2,20 \\
\hline Миколаївська & 67,24 & 32,76 & 0,00 \\
\hline Крим & 69,23 & 30,77 & 0,00 \\
\hline Івано-Франківська & 71,30 & 27,83 & 0,87 \\
\hline Кировоградська & 71,43 & 28,57 & 0,00 \\
\hline Хмельницька & 72,94 & 25,88 & 1,18 \\
\hline Закарпатська & 73,17 & 26,83 & 0,00 \\
\hline Тернопільська & 77,33 & 22,67 & 0,00 \\
\hline
\end{tabular}

*Розроблено автором із використанням джерел [11]

Проводячи аналіз форм власності та форм господарювання діючих м'ясопереробних підприємств України, можна зробити висновки, що дійсно, приватна форма власності притаманна більше м'ясопереробним підприємствам західного регіону України. Наприклад, в Закарпатській області вони становлять $73,17 \%$, а в Тернопільській - 77,33\%.
Для Одеської області не спостерігається будь-якої переваги форми власності (49,06 \% суб'єктів господарювання приватної власності та $50,94 \%$ - колективної). За формами господарювання ці суб'єкти господарювання розподілені наступним чином

(рис.1).

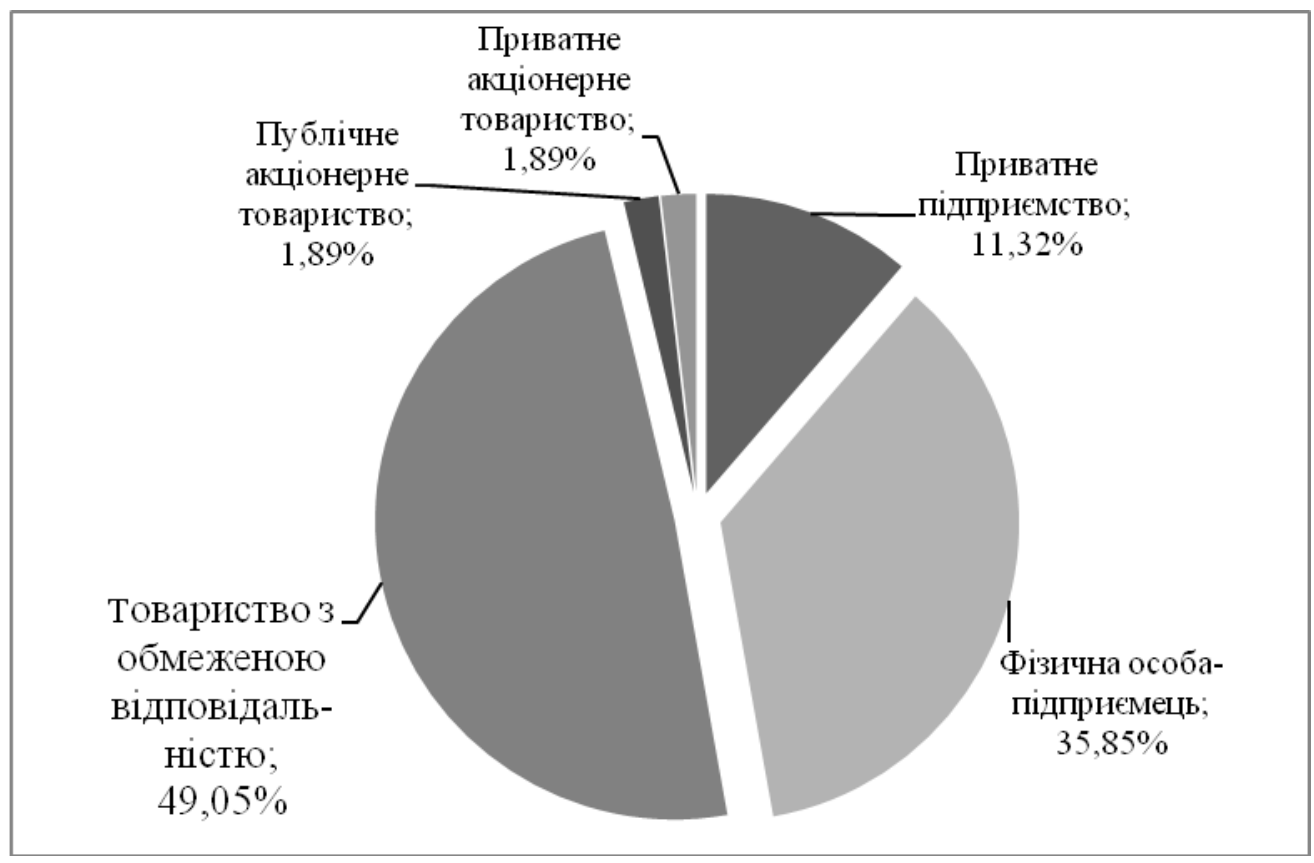

Рис. 1 - Структура форм господарювання м'ясопереробних підприсмств в Одеській області, \% *

* складено автором із використанням джерел [11]

Роль державної власності має бути в забезпеченні балансу територіального розвитку. Неможливо державну власність розділяти за політикоолігархічними структурами, особливо це стосується стратегічних галузей і об'єктів.

В сучасних умовах кризи розвитку економіки України, необхідно збільшити роль держави в регулюванні соціально-економічних процесів, які б були спрямовані на не перерозподіл власності, а на створення дійсного конкурентного середовища. Це в першу чергу, антимонопольне регулювання в енергетичному секторі, ЖКХ, в формуванні державних стандартів, створення однакових умов для всіх суб'єктів господарювання. Всі моделі сучасних ринкових відносин мають власні особливості з формування і функціонування господарської діяльності [2, с. 71-77].

Глобалізація в економіці, фінансах та інших соціально-економічних процесах передбачає обов'язкове втручання держави для захисту інтересів власне суспільства. Про необхідність державного регулювання і наявність державної влади в економіці вказують і лауреати Нобелівської премії в області економіці Дж.Тобін [3] та Дж.Стігліц [4].

Іншим питанням $є$ зміна організаційноекономічної моделі управління даними галузями i об'єктами. Тобто управління повинно здійснюватись 
не шляхом командно-адміністративних рішень, а за допомогою економічних важелів і стимулів через фінансово-кредитну політику та систему оподаткування.

Виходячи зі всіх названих умов і характеристик власності, під впливом яких функціонує економіка України, ми можемо стверджувати про деформацію відносин власності, що не спрямована на розвиток виробництва; привласнення та споживання матеріальних благ і вигод відповідно трудового вкладу. Це призвело до зруйнування економіки країни шляхом боротьби за перерозподіл власності між окремими групами олігархів тієї чи іншої політичної належності, яка перебуває при владі. Цю ситуацію в країні відмічають Павлишенко М. [5, с.54], Будкін В. [6, с. 39-42], Кіндзерський Ю. [7, с.8], Данько М. [8, с. 54] та інші економісти.

3 точки зору розвитку країни, власність і власники повинні бути, в першу чергу, зв'язані з виробництвом. Тут можна погодитися 3 Павлишенком М., який вважає, що перш за все, ніж присвоїти, i, як слідство, - спожити ту чи іншу річ, іiі необхідно виготовити. Саме виробництво, а не споживання є першоосновою відносин власності. ...«присвоїти можливо лише те та стільки, що саме та скільки вироблено» $[5$, c. 54]. ліджень.

Висновки та перспективи подальших дос-

В процесі дослідження нами були розглянуті особливості різних форм, видів і типів власності, їх переваги і недоліки для становлення і розвитку сучасних ринкових відносин, які впливають на розвиток соціально-економічних, організаційних та виробничих процесів в суспільстві. Всі види і форми власності, а також форми господарювання мають однакові права на існування, але їхнє застосування залежить від особливостей та менталітету регіонів країни.
В умовах економічної, фінансової і політичної кризи в Україні, глобалізації соціальноекономічних процесів потрібно підвищувати роль державної власності, а не знищувати іiі, для захисту інтересів суспільства, вітчизняного виробника шляхом зміни організаційно-економічної моделі управління на всіх рівнях.

Особливості харчової промисловості, в тому числі м'ясопереробної галузі полягають у тому, що для них характерним є наявність середнього і малого бізнесу, який заснований здебільшого на нетрудовій приватній та колективній власності. В Одеській області він представлений у вигляді зареєстрованих фізичних осіб - підприємців, приватних підприємств, товариств 3 обмеженої відповідальністю та акціонерних товариств. В перспективі можуть бути створені концерни і холдинги не за назвою, як це зараз є в Україні, а за сутністю. Це можливо, коли на ринку будуть конкурувати декілька олігополій.

В м'ясопереробній галузі України повинні функціонувати підприємства 3 різними формами власності, які б забезпечували оптимізацію виробництва в різних регіонах країни в залежності від наявності ресурсів та кількості населення.

Для ефективного функціонування сучасного ринкового господарства України необхідно змінити цілі та місію підприємств. В першу чергу, вони повинні бути спрямовані на задоволення потреб населення якісними товарами та послугами не залежно від виду і форм власності. Тільки це може бути підставою для отримання довгострокового прибутку, який забезпечить економічний і соціальний прогрес господарства та його робітників.

Тому подальше дослідження форм і видів власності повинне бути спрямовано на аналіз результативності діючих форм власності і прогнозних можливостей ефективності їх використання.

\section{Література}

1. Мандибура В. Системно-формаційна трансформація інституту власності / В. Мандибура // Економічна теорія. -2013 . - № 2. - С.57-73.

2. Симоненко В. Государство и рынок: пути партнерства / В. Симоненко // Економіка України. - 2007. - №1. - С. 71-77.

3. Тобин Дж. Теорема о невидимой руке должна быть модифицирована / Дж.Тобин // Российский экономический журнал. - 2002. - №3. - С. 44-45.

4. Стиглиц Дж. Глобализация: тревожные тенденции / Дж. Стиглиц. - М.: Мысль. - 2003. -255 с.

5. Павлишенко М. Про відділення власті від бізнесу / М. Павлишенко // Економіка України. - 2007. №2. - С. 53-61.

6. Будкін В. Постсоціалістична трансформація власності / В. Будкін // Економіка України. - 2007. №2. - С. 39-44.

7. Кіндзерський Ю. Інституціональні аспекти відтворення у контексті структури трансформацій / Ю. Кіндзерський // Економіка України. - 2007. - №1. - С.4-13.

8. Данько М. Реорганізація підприємств у контексті формування корпоративних структур / М.Данько // Економіка України. - 2007. - №1. - С.64-70.

9. Степаненко С.В. Трансформація відносин власності в умовах формування постіндустріальної економіки / С.В. Степаненко, Л.І. Яковенко. - Полтава: Скайтек. - 2009. - 187 с.

10. Сайт державної служби статистики України [Електронний ресурс]. - Режим доступу: http://www.ukrstat.gov.ua/ 
11. Сайт державної ветеринарної та фітосанітарної служби України [Електронний ресурс]. - Режим доступу: http://vet.gov.ua/sites/default/files/factories/pererob45.doc

\author{
Магденко С.А. \\ ассистент \\ кафедра экономики промышленности \\ Одесская национальная академия пищевых технологий \\ ул. Канатная, 112, г. Одесса, Украина, 65039 \\ E-mail: maglana@meta.ua
}

\title{
ОТНОШЕНИЯ СОБСТВЕННОСТИ КАК ОСНОВНАЯ СОСТАВЛЯЮЩАЯ ФОРМИРОВАНИЯ СОВРЕМЕННОГО РЫНОЧНОГО ХОЗЯЙСТВА УКРАИНЫ
}

\begin{abstract}
Формы проявления собственности в исторической перспективе постоянно меняются и совершенствуются в соответствии с изменениями, происходящими в производительных силах общества. Рост масштабов производства, его усложнение, абсолютное увеличение населения на планете, возрастание его потребностей способствовали появлению новых проблем различного общественного характера - от экономического и, социального до экологического. Классическая (личная) частная собственность и основанная на ней рыночная экономика не способна решить эти проблемы.

В связи с этим возникают и приобретают все большее значение новые формы частной собственности, предусматривающие переход от индивидуальной к обобществленной частной собственности. Государственная же собственность должна приобретать общественный характер. То есть, должна действовать не только в интересах определенных слоев общества, но и в интересах большинства его членов.
\end{abstract}

В работе рассмотрены вопросы форм, типов и видов собственности, присущие современному рыночному хозяйству, тенденции формирования современных фрорм собственности, их взаимосвязь с формами хозяйствования предприятий пищевой промышленности.

Для эффективного функционирования рыночного хозяйства Украины необходимо изменение цели и миссии предприятий. В первую очередь, они должны быть направлены на удовлетворение потребностей населения качественными товарами и услугами. И только это должно быть основой для получения долгосрочной прибыли, затрачиваемое на собственное потребление и на совершенствование техники и технологии производства и управления.

С этой целью автором проанализированы виды и фрормы собственности, определена их структура в разрезе регионов Украины, проанализировано распределение субъектов хозяйствования по организационным формам. Раскрыта сущность различных фрорм собственности, их преимущества и недостатки на современном этапе развития рыночного хозяйства в Украине. Рассмотрена роль государственной собственности в процессе становления и развития современного рыночного хозяйства. В процессе исследования предприятий пищевой промышленности, в том числе, мясоперерабатывающей отрасли, наиболее характерным является развитие среднего и малого бизнеса, которые и в ближайшей перспективе будут господствовать в экономике.

Ключевые слова: собственность, формы собственности, виды собственности, фрормы хозяйствования, эффрективность, рыночное хозяйство, субъект хозяйствования.

\author{
Magdenko S.O. \\ Assistant \\ Department of Industrial Economics \\ Odessa National Academy of Food Technologies \\ Kanatna str., 112, Odessa, Ukraine, 65039 \\ E-mail:maglana@meta.ua
}

\section{THE RELATIONSHIP PROPERTY AS A MAIN COMPONENT OF THE FORMATION OF A MODERN MARKET ECONOMY OF UKRAINE}

The article examines the forms, types and forms of ownership inherent in the modern market economy, the trend of the formation of modern forms of property, their relationship with the forms of management 
of the food industry.

The genesis of the formation of collective and state ownership of the economy of any state begins with private property. However, further development of the forms and types of property in Ukraine leads back to private property, which is already represented by politicians as the distribution of state and collective ownership between members of the community with a separate share of the property. In other words speaking, by "democratization of capital". As a result of denationalization and privatization of a merger of business and politics. That is carried out in the 1990s, the privatization of which was to be a key factor in Ukraine out of a deep systemic crisis, failed to meet expectations. In many cases, the owner does not appear effective. Also creates an imbalance of private and public interests, often due to the failure of investors commitments.

The forms of manifestation of property in historical perspective are constantly changing and improving in line with the changes in the productive forces of society.

Economies of scale, its complexity, the absolute increase in population on the planet, the increase in its needs have contributed the emergence of new problems of different social character - from economic and social to environmental. Classical (personal) private property and it is based on a market economy can not solve these problems.

In connection with this start to occur and become increasingly important new forms of private ownership, providing for the transition from the individual to the socialization of private property. State property should also acquire a social character. That is, should not act only in the interests of certain sectors of society, but also in the interests of the majority of its members.

For the effective functioning of the market economy in Ukraine is necessary to change the goals and mission of the enterprise. First of all, they should be designed to meet the needs of the population with quality goods and services. And only this should be the basis for long-term profit spent on their own consumption and to improve the techniques and technologies of production and management.

Keywords: property, ownership, types of property, forms of management, efficiency, market economy, the economic entity.

\section{References}

1. Mandybura, V. (2013). Systemno-formatsiina transformatsiia instytutu vlasnosti. Ekonomichna teoriia, (2), $57-73$.

2. Symonenko, V. (2007). Hosudarstvo y runok: Puty partnerstva. Ekonomika Ukrainy, (1), 71-77.

3. Tobyn, D. (2002). Teorema o nevydymoi ruke dolzhna but modyfytsyrovana. Rossyiskyi Ekonomycheskyi Zhurnal, (3), 44-45.

4. Styhlyts, D. (2003). Hlobalyzatsyia: Trevozhnue tendentsyy / (p. 255). Moskva: Musl.

5. Pavlyshenko, M. (2007). Pro viddilennia vlasti vid biznesu. Ekonomika Ukrainy, (2), 53-61.

6. Budkin, V. (2007). Postsotsialistychna transformatsiia vlasnosti. Ekonomika Ukrainy, (2), 39-44.

7. Kindzerskyi, I. (2007). Instytutsionalni aspekty vidtvorennia u konteksti struktury transformatsii. Ekonomika Ukrainy, (1), 4-13.

8. Danko, M. (2007). Reorhanizatsiia pidpryiemstv u konteksti formuvannia korporatyvnykh struktur. Економіка України, (1), 64-70.

9. Stepanenko, S., \& Yakovenko, L. (2009). Transformatsiia vidnosyn vlasnosti v umovakh formuvannia postindustrialnoi ekonomiky (p. 187). Poltava: Skaitek.

10. Derzhavna sluzhba statystyky Ukrainy. (2014, November 16). Retrieved October 1, 2015, from http://www.ukrstat.gov.ua/

11. Derzhavna veterynarnata fitosanitarnasluzhba Ukrainy. (2014, October 4). Retrieved October 1, 2015, from http://vet.gov.ua/sites/default/files/factories/pererob45.doc

Received 12 October 2015

Approved 26 October 2015

Available in Internet 26.12.2015 